\title{
PENGARUH DEMOGRAFI, PSIKOSOSIAL DAN LAMA MENDERITA HIPERTENSI PRIMER TERHADAP KEPATUHAN MINUM OBAT ANTIHIPERTENSI
}

\author{
Chandra Tri Wahyudi ${ }^{1}$, Diah Ratnawati², Sang Ayu Made ${ }^{3}$ \\ ${ }^{1}$ Universitas Pembangunan Nasional "Veteran" Jakarta ${ }^{2}$ Universitas Pembangunan Nasional \\ "Veteran" Jakarta ${ }^{3}$ Universitas Pembangunan Nasional "Veteran" Jakarta \\ Email: ${ }^{1}$ chan.tw.1987@gmail.com,Ratnawatidiah@gmail.com,udek_yani@yahoo.com
}

\begin{abstract}
ABSTRAK
Hipertensi adalah adanya peningkatan tekanan systole diatas $140 \mathrm{mmhg}$ dan diastole diatas 90 mmhg. Hipertensi masih menjadi masalah kesehatan di Indonesia. Penurunan angka mortalitas menjadi indikator keberhasilan pengobatan hipertensi. Studi pendahuluan menunjukkan masyarakat dalam meminum obat antihipertensi masih tergolong rendah. Penelitian ini bertujuan mengetahui pengaruh demografi, psikosial dan lama menderita hipertensi primer yang berhubungan dengan tingkat kepatuhan pasien dalam minum obat antihipertensi di Kelurahan Limo Depok 2017. Tehnik pengambilan sampel dengan menggunakan Simple Random Sampling. Penelitian ini menggunakan metode Deskriptif analitik dengan analisa data yang digunakan adalah Analisa data bivariat yaitu uji chisquare dan untuk analisa multivariat menggunakan uji regresi logistik. Hasil penelitian menunjukkan subvariabel sikap dari variabel psikososial yang paling berhubungan dengan kepatuhan minum obat dengan $p$ value $0,001<0,05$. Nilai OR terbesar yang diperoleh yaitu 21,860 artinya sikap baik yang dimiliki responden mempunyai peluang 21,860 kali untuk patuh minum obat antihipertensi. Hasil penelitian ini diharapkan memberikan dampak untuk lebih disiplin dalam mengkonsumsi obat antihipertensi agar tidak terjadi komplikasi akibat hipertensi.
\end{abstract}

Kata kunci: Hipertensi, kepatuhan, obat anti hipertensi

\section{PENDAHULUAN}

Dewasa awal dan tengah adalah periode yang penuh tantangan, penghargaan dan krisis. Tantangan ini meliputi tuntunan kerja dan membentuk keluarga, meskipun orang dewasa juga dapat diberi penghargaan karena kesuksesan karier mereka dan kehidupan pribadi mereka. Orang dewasa juga menghadapi krisis seperti kehilangan pekerjaan dengan berubah lingkungan ekonomi dan menghadapi kebutuhan perkembangan mereka sendiri seperti juga kebutuhan anggota keluarga mereka. Krisis inilah yang menjadi predisposisi terjadinya peningkatan tekanan darah. Menurut Perhimpunan Dokter Spesialis Kardiovaskuler Indonesia (Perki,2015), Hipertensi adalah salah satu penyebab utama mortalitas dan morbiditas di Indonesia, sehingga tatalaksana penyakit ini merupakan intervensi yang sangat umum dilakukan diberbagai tingkat fasilitas kesehatan. Hampir semua consensus/ pedoman utama baik dari dalam walaupun luar negeri, menyatakan bahwa seseorang akan dikatakan hipertensi bila memiliki tekanan darah sistolik $\geq 140$ $\mathrm{mmHg}$ dan atau tekanan darah diastolik $\geq$ 
$90 \mathrm{mmHg}$, pada pemeriksaan yang berulang. Tekanan darah sistolik merupakan pengukuran utama yang menjadi dasar penentuan diagnosis hipertensi.

Hipertensi juga sering tidak menimbulkan manifestasi sehingga disebut sebagai silent killer, sementara tekanan darah yang terus menerus tinggi dalam jangka waktu lama dapat menimbulkan komplikasi. Oleh karena itu, hipertensi perlu dideteksi dini yaitu dengan pemeriksaan tekanan darah secara berkala(kontrol tekanan darah) (Depkes RI, 2012). Menurut American Heart Association $\{A H A\}$, penduduk Amerika yang berusia diatas 20 tahun menderita hipertensi telah mencapai angka hingga 74,5 juta jiwa, namun hamper sekitar 9095\% kasus tidak diketahui penyebabnya. Selain menurut Depkes, Hipertensi juga merupakan silent killer dimana gejala dapat bervariasi pada masing-masing individu dan hampir sama dengan gejala penyaki lainnya. Gejala-gejalanya itu adalah saki kepala/rasa berat di tengkuk, mumet (vertigo), jantung. berdebar-debar, mudah Ielah, penglihatan kabur, telinga berdenging (tinnitus), dan mimisan. Menurut World Health Organization (WHO) tahun 2012 Hipertensi memberikan kontribusi untuk hampir 9,4 juta kematian akibat penyakit kardiovaskuler setiap tahun. Hal ini juga meningkatkan risiko penyakit jantung koroner sebesar $12 \%$ dan meningkatkan risiko stroke sebesar $24 \%$ (WHO, 2012). Setiap tahunnya, penyakit hipertensi telah membunuh 9,4 juta jiwa penduduk di seluruh dunia. WHO juga telah memperkirakan bahwa jumlah pengidap hipertensi akan terus meningkat seiring dengan pertambahan jumlah penduduk. Dan WHO juga memprediksi bahwa pada tahun 2025 yang akan datang, ada sekitar $29 \%$ jiwa di dunia yang terserang penyakit hipertensi.

Menurut data Riskesdas tahun 2013, bahwa Prevalensi hipertensi di Indonesia yang didapat melalui pengukuran pada umur $\geq 18$ tahun sebesar 25,8 persen, tertinggi di Bangka Belitung (30,9\%), diikuti Kalimantan Selatan (30,8\%), Kalimantan Timur $(29,6 \%)$ dan Jawa Barat $(29,4 \%)$. Prevalensi hipertensi di Indonesia yang didapat melalui kuesioner terdiagnosis tenaga kesehatan sebesar 9,4 persen, yang didiagnosis tenaga kesehatan atau sedang minum obat sebesar 9,5 persen. Jadi, ada 0,1 persen yang minum obat sendiri. Responden yang mempunyai tekanan darah normal tetapi sedang minum obat hipertensi sebesar 0.7 persen. Jadi prevalensi hipertensi di Indonesia sebesar 26,5 persen. Menurut data dinas kesehatan Kota depok tahun 2013, prevalensi Hipertensi Primer menduduki urutan pertama dengan presentase $53,9 \%$ atau sebanyak 19275 penduduk (Profile Kesehatan Kota Depok,2013). Data dari puskesmas Limo Kelurahan Limo Kota Depok didapatkan presentase penyakit hipertensi $13 \%$ dari 10 Penyakit (Puskesmas Limo,2014). Data yang didapat dari hasil survey Praktek Keperawatan Komunitas pada bulan Januari 2016 di wilayah RW 15 pada RT 01,02 dan ) 3 Kelurahan Limo Kecamatan Limo Depok didapatkan data masalah kesehatan tertinggi yang pertama yaitu masalah kesehatan hipertensi dengan presentase sebesar $54 \%$ dari 12 penyakit yang ditemukan. (Laporan PKL Keperawatan Komunitas,2016). Banyaknya warga RW 15 yang menderita hipertensi salah satunya disebabkan dari pola makan, karena kebiasaan warga yang sering mengkonsumsi ikan asin dan tidak patuhnya dalam meminum obat antihipertensi. Dari studi pendahuluan Januari 2017 berdasarkan wawancara dari 20 orang yang menderita hipertensi primer di kelurahan Limo Depok terdapat 14 orang tidak teratur meminum obat antihipertensi hanya meminum obat apabila sakit kepala yang dirasakan sudah tidak tertahan, 4 orang yang meminum obat antihipertensi (kaptopril 1 x $1 \mathrm{mg}$ ) secara teratur dan 2 orang tidak meminum obat antihipertensi.

Tidak terkontrolnya masyarakat yang menderita hipertensi akan memicu 
terjadinya komplikasi lebih lanjut seperti penyakit kardiovaskular. Penyakit jantung, Stroke dan Ginjal merupakan resiko komplikasi penyakit kardiovaskuler yang sering terjadi. Penggunaan obat anti hipertensi saat ini masih efektif dalam penanggulanggan hipertensi. Masyarakat saat ini masih mempunyai pola meminum obat anti hipertensi tidak diminum secara rutin,hanya diminum pada saat tekanan darah meningkat saja. Hal ini yang menyebabkan komplikasi dari hipertensi terjadi.Kepatuhan pengobatan pasien hipertensi merupakan hal penting karena hipertensi merupakan penyakit yang tidak dapat disembuhkan tetapi harus selalu dikontrol atau dikendalikan agar tidak terjadi komplikasi yang dapat berujung pada kematian (Palmer dan William, 2007). Problem ketidakpatuhan umum dijumpai dalam pengobatan penyakit kronis yang memerlukan pengobatan jangka panjang seperti hipertensi. Obat-obat antihipertensi yang ada saat ini telah terbukti dapat mengontrol tekanan darah pada pasien hipertensi, dan juga sangat berperan dalam menurunkan risiko berkembangnya komplikasi kardiovaskular. Namun demikian, penggunaan antihipertensi saja terbukti tidak cukup untuk menghasilkan efek pengontrolan tekanan darah jangka panjang apabila tidak didukung dengan kepatuhan dalam menggunakan antihipertensi tersebut (Saepudin dkk, 2011)

Menurut hasil penelitian Puspita, (2016) Dari hasil penelitian ini dapat disimpulkan bahwa faktor tingkat pendidikan terakhir $(p=0,000)$, lama menderita hipertensi $(p=0,005)$, tingkat pengetahuan tentang hipertensi $(p=0,000)$, dukungan keluarga $(p=0,000)$, peran petugas kesehatan $(p=0,000)$, motivasi berobat $\quad(p=0,000)$ memiliki hubungan dengan kepatuhan dalam menjalani pengobatan hipertensi. Dan menurut Pratama Wahyu G dan Ariastuti Putu Tahun 2014, dari 97 orang sampel, 62 (63.9\%) sampel memiliki kepatuhan rendah dan $36.1 \%$ sampel memiliki kepatuhan tinggi terhadap pengobatan hipertensi. Hasil uji statistik pada faktor - faktor yang mempengaruhi kepatuhan menunjukkan hasil yang signifikan pada; tingkat pengetahuan $(\mathrm{p}=0.015)$, motivasi $(\mathrm{p}=0.02)$, dukungan petugas $(\mathrm{p}=0.048)$ dan dukungan keluarga $(\mathrm{p}=0.000)$. Dari penjelasan diatas bahwa kepatuhan dalam meminum obat antihipertensi masih dominan rendah dan masih beberapa variabel yang belum diteliti sehingga peneliti tertarik untuk melakukan penelitian dengan variabel yang berbeda dengan judul "Pengaruh demografi, psikososial dan lama Menderita hipertensi terhadap kepatuhan minum obat antihipertensi di Kelurahan Limo,Depok “.

\section{Hipertensi}

Hipertensi didefinisikan sebagai tekanan sistolik 160 mmhg dan tekanan diastolic 90 mmhg (Brunner \& Suddarth, 2005). Klasifikasi tekanan darah oleh JNC 7 untuk pasien dewasa (umur $\geq 18$ tahun) berdasarkan rata-rata pengukuran tekanan darah atau lebih pada dua atau lebih kunjungan klinis (Tabel 2.1). Klasifikasi tekanan darah mencakup 4 kategori, dengan nilai normal pada tekanan darah sistolik (TDS) $<120 \mathrm{mmHg}$ dan tekanan darah diastolik (TDD) <80 mmHg. Pre-hipertensi tidak dianggap sebagai kategori penyakit tetapi mengidentifikasi pasien-pasien yang tekanan darahnya cenderung meningkat ke klasifikasi hipertensi dimasa yang akan datang. Ada dua tingkat (stage) hipertensi, dan semua pasien pada kategori ini harus diterapi obat.

Tabel 1.1 Klasifikasi Hipertensi (Sumber : JNC VII, 2003)

\begin{tabular}{|l|l|l|}
\hline \multicolumn{1}{|c|}{ Derajat } & \multicolumn{1}{|c|}{$\begin{array}{c}\text { Tekanan } \\
\text { Sistolik } \\
(\mathrm{mmhg})\end{array}$} & \multicolumn{1}{|c|}{$\begin{array}{c}\text { Tekanan } \\
\text { Diastolik } \\
(\mathrm{mmhg})\end{array}$} \\
\hline Normal & $<120$ & Dan $<80$ \\
\hline Pre-hipertensi & $120-139$ & atau $80-89$ \\
\hline $\begin{array}{l}\text { Hipertensi } \\
\text { derajat I }\end{array}$ & $140-159$ & atau $90-99$ \\
\hline $\begin{array}{l}\text { Hipertensi } \\
\text { derajat II }\end{array}$ & $\geq 160$ & Atau $\geq 100$ \\
\hline
\end{tabular}


Hipertensi dibedakan menjadi hipertensi primer yaitu hipertensi yang tidak diketahui penyebabnya dan hipertensi sekunder yaitu hipertensi yang muncul akibat adanya penyakit lain seperti hipertensi ginjal, hipertensi kehamilan, dan lain-lain (Dinkes Jateng, 2012). faktor genetik memegang peranan penting pada patogenesis hipertensi primer. Faktor-faktor lain yang dapat dimasukan dalam daftar penyebab hipertensi jenis ini adalah lingkungan, kelainan metabolisme intra seluler, dan faktor-faktor yang meningkatkan risikonya seperti obesitas, konsumsi alkohol, merokok dan kelainan darah (Muchid, 2006). Tidak semua penderita hipertensi mengenali atau merasakan keluhan maupun gejala, sehingga hipertensi sering dijuluki pembunuh diam-diam (silent killer). Keluhan-keluhan yang tidak spesifik pada penderita hipertensi antara lain: sakit kepala, gelisah, jantung berdebar-debar, pusing, penglihatan kabur, rasa sakit didada, mudah lelah dll (Depkes RI, 2013). Komplikasi hipertensi dapat terjadi pada organ-organ seperti gagal jantung,jantung coroner, stroke, gagal ginjal, dan retinopati. Penatalaksanaan farmakologi pada hipertensi dimulai bila pada pasien hipertensi derajat 1 yang tidak mengalami penurunan tekanan darah setelah $>6$ bulan menjalani pola hidup sehat dan pada pasien dengan hipertensi derajat $\geq 2$. Beberapa prinsip dasar terapi farmakologi yang perlu diperhatikan untuk menjaga kepatuhan dan meminimalisasi efek samping, yaitu :Bila memungkinkan, berikan obat dosis tunggal, Berikan obat generic (non-paten) bila sesuai dan dapat mengurangi biaya, Berikan obat pada pasien usia lanjut ( diatas usia 80 tahun ) seperti pada usia $55-80$ tahun, dengan memperhatikan faktor komorbid Jangan mengkombinasikan angiotensin converting enzyme inhibitor (ACE-i) dengan angiotensin II receptor blockers (ARBs), Berikan edukasi yang menyeluruh kepada pasien mengenai terapi farmakologi

\section{Perilaku Kepatuhan}

Kepatuhan adalah sebagai perilaku untuk menaati saran-saran dokter atau prosedur dari dokter tentang penggunaan obat, yang sebelumnya didahului oleh proses konsultasi antara pasien (keluarga pasien sebagai orang kunci dalam kehidupan pasien) dengan dokter sebagai penyedia jasa medis (Siti Noor Fatmah ,2012). Keberhasilan pengobatan pada pasien hipertensi dipengaruhi oleh beberapa faktor yaitu peran aktif pasien dan kesediaanya untuk memeriksakan ke dokter sesuai dengan jadwal yang ditentukan serta kepatuhan dalam meminum obat antihipertensi. Faktor- Faktor yang mempengaruhi Kepatuhan terdiri dari Demografi Meliputi usia, jenis kelamin, suku bangsa, status pekerjaan dan pendidikan. Umur merupakan faktor yang penting dimana anak-anak terkadang tingkat kepatuhannya jauh lebih tinggi daripada remaja. Perbedaan pola perilaku sakit juga dipengaruhi oleh jenis kelamin, perempuan lebih sering mengobatkan dirinya dibandingkan dengan laki-laki (Notoatmodjo, 2010), Orang yang bekerja cenderung memiliki sedikit waktu untuk mengunjungi fasilitas kesehatan (Notoatmodjo, 2007). Semakin tinggi pendidikan seseorang, maka akan memudahkan seseorang menerima informasi sehingga meningkatkan kualitas hidupdan menambah luas pengetahuan. Psikososial meliputi sikap pasien terhadap tenaga kesehatan serta menerima terhadap penyakitnya. Sikap seseorang terhadap perilaku kepatuhan menentukan tingkat kepatuhan. Kepatuhan seseorang merupakan hasil dari proses pengambilan keputusan orang tersebut, dan akan berpengaruh pada persepsi dan keyakinan orang tentang kesehatan. Selain itu keyakinan serta budaya juga ikut menentukan perilaku kepatuhan. Nilai seseorang mempunyai keyakinan bahwa anjuran kesehatan itu dianggap benar maka kepatuhan akan semakin baik. Lama menderita hipertensi dikatakan Semakin lama seseorang menderita hipertensi maka 
tingkat kepatuhanya makin rendah, hal ini disebabkan kebanyakan penderita akan merasa bosan untuk berobat (Ketut Gama et al, 2014). Menurut Puspita, 2016 ,hubungan antara lama menderita hipertensi dengan kepatuhan dalam menjalani pengobatan hipertensi diperoleh nilai $p$ velue $=0,005(\mathrm{p}<0,05)$ yang berarti bahwa ada hubungan antara lama menderita hipertensi dengan kepatuhan dalam menjalani pengobatan hipertensi.

\section{Keperawatan Komunitas}

Keperawatan komunitas adalah pelayanan keperawatan professional yang ditunjukan pada masyarakat dengan penekanan kelompok risiko tinggi dalam upaya pencapaian derajat kesehatan yang optimal melalui peningkatan kesehatan, pencegahan penyakit, pemeliharaan dan rehabilitasi dengan menjamin keterjangkauan pelayanan kesehatan yang dibutuhkan dan melibatkan klien sebagai mitra dalam perencanaan, pelaksanaan, dan evaluasi (Community Health Nursing, 1999). Peran perawat komunitas yaitu pemberi pelayanan kesehatan, penemu kasus, Pendidik/Penyuluhan Keperawatan, Koordinator, Kolaborator, Penghubung, Konselor, Model Peran (role Model).

\section{HIPOTESIS}

a) Ada Hubungan usia dengan perilaku kepatuhan meminum obat antihipertensi di Wilayah kelurahan Limo Depok Tahun 2017

b) Ada Hubungan Jenis Kelamin dengan perilaku kepatuhan meminum obat antihipertensi di Wilayah kelurahan Limo Depok Tahun 2017

c) Ada Hubungan pendidikan dengan perilaku kepatuhan meminum obat antihipertensi di Wilayah kelurahan Limo Depok Tahun 2017

d) Ada Hubungan Sikap dengan perilaku kepatuhan meminum obat antihipertensi di Wilayah kelurahan Limo Depok Tahun 2017

e) Ada Hubungan Lama Menderita dengan perilaku kepatuhan meminum obat antihipertensi di Wilayah kelurahan Limo Depok Tahun 2017

f) Adanya faktor yang sangat mempengaruhi perilaku kepatuhan meminum obat antihipertensi di wilayah kelurahan limo Depok tahun 2017

\section{METODOLOGI PENELITIAN}

Penelitian ini menggunakan metode Deskriptif Analitik dengan desain penelitian "cross sectional" dimana variabel sebab akibat dengan variabel bebas yaitu faktorfaktor yang mempengaruhi kepatuhan minum obat antihipertensi dan variabel terikat yaitu kepatuhan minum obat antihipertensi. Subjek yang digunakan adalah pasien dengan hipertensi primer yang ada wilayah kelurahan limo,Depok. Tehnik pengambilan sampel dengan menggunakan Simple Random Sampling sebanyak 174 responden. Penelitian ini tidak melakukan intervensi dan hanya menyebarkan kuisioner. Analisa data yang digunakan adalah analisa univariat, bivariat dan multivariat. Untuk analisa data bivariat yang digunakan adalah uji chi-square dan uji multivariat yang digunakan adalah uji regresi logistik.

\section{HASIL DAN PEMBAHASAN}

Persetujuan etik dari komisi Etik Penelitian Kesehatan (KEPK) UPN "Veteran" Jakarta untuk penelitian dibuktikan dengan surat persetujuan Etik Nomor : KEP/400/UN61/2016 tanggal 1 Juni 2016 tentang kalender Akademik UPN "Veteran" Jakarta TA.2016/2017.

\section{Hasil}

\section{a. Hasil Univariat}

Tabel 1.

Distribusi Frekuensi Usia Responden pada Penderita Hipertensi Primer di Kelurahan Limo Depok $2017 \quad(n=173)$

\begin{tabular}{|c|c|c|}
\hline Usia & Frekuensi & Persen \\
\hline $\begin{array}{c}\text { Dewasa } \\
\text { Awal }\end{array}$ & 21 & 12,1 \\
\hline $\begin{array}{c}\text { Dewasa } \\
\text { Tengah }\end{array}$ & 100 & 57,8 \\
\hline $\begin{array}{c}\text { Dewasa } \\
\text { Akhir }\end{array}$ & 52 & 30,1 \\
\hline
\end{tabular}


Hasil analisis data pada tabel menunjukkan bahwa karakteristik dari 173 responden di Kelurahan Limo Depok tahun 2017 sebagian besar berusia dewasa tengah (36 - 45 tahun) sebanyak 100 responden $(57,8 \%)$ sedangkan berusia dewasa akhir (46 - 55 tahun) sebanyak 52 responden $(\% 30,1)$ dan sisanya berusia dewasa awal (26 - 35 tahun) sebanyak responden $(12,1 \%)$.

Tabel 2. Distribusi Jenis Kelamin Responden pada Penderita Hipertensi Primer di Kelurahan Limo Depok 2017 $(n=173)$

\begin{tabular}{ccc}
\hline Jenis Kelamin & Frekuensi & Persen \\
\hline Perempuan & 125 & 72,3 \\
\hline Laki-Laki & 48 & 27,8 \\
\hline
\end{tabular}

Hasil analisis data pada tabel menunjukkan bahwa karakteristik dari 173 responden di Kelurahan Limo Depok tahun 2017 sebagian besar berjenis kelamin perempuan sebanyak 125 responden $(72,3 \%)$ dan sisanya sebanyak 48 responden $(27,8 \%)$ berjenis kelamin lakilaki.

Tabel 3 .Distribusi Frekuensi Suku Responden pada Penderita Hipertensi

Primer di Kelurahan Limo Depok 2017 $(n=173)$

\begin{tabular}{ccc}
\hline Suku Bangsa & Frekuensi & Persen \\
\hline Jawa & 34 & 19,7 \\
\hline Sunda & 39 & 22,5 \\
\hline Betawi & 98 & 56,6 \\
\hline Lain-Lain & 2 & 1,2 \\
\hline
\end{tabular}

Analisis data pada tabel menunjukkan bahwa karakteristik dari 173 responden di Kelurahan Limo Depok tahun 2017 sebagian besar bersuku Betawi sebanyak 98 responden $(56,6 \%)$ sedangkan suku Sunda sebanyak 39 responden $(22,5 \%)$ berbeda sedikit dengan suku Jawa sebanyak 34 responden $(19,7 \%)$ dan sisanya lain-lain sebanyak 2 responden $(2 \%)$.
Tabel 4. Distribusi Pendidikan Responden pada Penderita Hipertensi Primer di Kelurahan Limo Depok 2017 $(n=173)$

\begin{tabular}{ccc}
\hline Pendidikan & Frekuensi & Persen \\
\hline Tinggi & 74 & 42,8 \\
\hline Rendah & 99 & 57,2 \\
\hline
\end{tabular}

Hasil analisis data pada tabel menunjukkan bahwa karakteristik dari 173 responden di Kelurahan Limo Depok tahun 2017 sebagian besar berpendidikan rendah (SD,SMP) sebanyak 99 responden $(57,2 \%)$ dan sisanya sebanyak 74 responden $(42,8 \%)$ berpendidikan tinggi (SMA, Perguruan Tinggi).

Tabel 5. Distribusi Sikap Persepsi Responden pada Penderita Hipertensi Primer di Kelurahan Limo Depok 2017 $(n=173)$

\begin{tabular}{ccc}
\hline $\begin{array}{c}\text { Sikap } \\
\text { Persepsi }\end{array}$ & Frekuensi & Persen \\
\hline Baik & 84 & 48,6 \\
\hline Tidak Baik & 89 & 51,4 \\
\hline
\end{tabular}

Hasil analisis data pada tabel menunjukkan bahwa karakteristik dari 173 responden di Kelurahan Limo Depok tahun 2017 sebagian besar memiliki sikap persepsi yang tidak baik sebanyak 89 responden $(51,4 \%)$ dan sisanya memiliki sikap persepsi yang baik sebanyak 84 responden $(48,6 \%)$.

Tabel 6. Distribusi Lama Menderita

Hipertensi Responden pada Penderita

Hipertensi Primer di Kelurahan Limo Depok $2017(n=173)$

\begin{tabular}{ccc}
\hline $\begin{array}{c}\text { Lama } \\
\text { Sakit }\end{array}$ & Frekuensi & Persen \\
\hline Akut & 51 & 29,5 \\
\hline Kronis & 122 & 70,5 \\
\hline
\end{tabular}

Hasil analisis data pada tabel menunjukkan bahwa karakteristik dari 173 responden di Kelurahan Limo Depok tahun 2017 sebagian besar menderita hipertensi > 
6 bulan (kronis) sebanyak 122 responden $(70,5 \%)$ sisanya sebanyak 51 responden $(29,5 \%)$ menderita hipertensi $\leq 6$ bulan (akut).

Tabel 7. Distribusi Kepatuhan Minum Obat Responden pada Penderita Hipertensi Primer di Kelurahan Limo Depok 2017 $(n=173)$

\begin{tabular}{ccc}
\hline $\begin{array}{c}\text { Kepatuhan } \\
\text { Minum Obat } \\
\text { Antihipertensi }\end{array}$ & Frekuensi & Persen \\
\hline Patuh & 111 & 64,2 \\
\hline & & \\
\hline Tidak Patuh & 62 & 35,8 \\
\hline
\end{tabular}

Hasil analisis data pada tabel menunjukkan bahwa karakteristik dari 173 responden di Kelurahan Limo Depok tahun 2017 sebagian besar patuh minum obat antihiertensi sebanyak 111 responden $(64,2 \%)$ dan sisanya tidak patuh minum obat antihiertensi sebanyak 62 responden

\section{b. Analisis Bivariat}

Tabel 1. Analisis Hubungan Usia Dengan

Kepatuhan Minum Obat Antihipertensi

Pada Penderita Hipertensi Primer Di

Kelurahan Limo Depok tahun 2017

\begin{tabular}{|c|c|c|c|c|c|c|c|c|}
\hline \multirow{3}{*}{ Usia } & \multicolumn{6}{|c|}{ Kepatuhan Minum Obat } & \multirow{3}{*}{$\begin{array}{c}P- \\
\text { value }\end{array}$} & \\
\hline & \multicolumn{2}{|c|}{ Patuh } & \multicolumn{2}{|c|}{$\begin{array}{l}\text { Tidak } \\
\text { Patuh }\end{array}$} & \multicolumn{2}{|c|}{ Total } & & OR \\
\hline & $\mathbf{n}$ & $\%$ & $\mathbf{n}$ & $\%$ & $\mathbf{n}$ & $\%$ & & \\
\hline $\begin{array}{c}\text { Dewasa } \\
\text { Awal }\end{array}$ & 8 & 38,1 & 13 & 61,9 & 21 & 100 & \multirow{4}{*}{0,001} & \\
\hline $\begin{array}{l}\text { Dewasa } \\
\text { Tengah }\end{array}$ & 74 & 74,7 & 25 & 25,3 & 99 & 100 & & \\
\hline $\begin{array}{c}\text { Dewasa } \\
\text { Akhir }\end{array}$ & 28 & 53,8 & 24 & 46,3 & 52 & 100 & & \\
\hline Total & 110 & 64 & 62 & 36 & 172 & 100 & & \\
\hline
\end{tabular}

Hasil analisis dari tabel diatas, meyatakan bahwa dari 21 responden berusia 26-35 tahun (dewasa awal) terhadap kepatuhan minum obat, diketahui 8 responden $(28,1 \%)$ patuh minum obat dan 13 responden $(61,9 \%)$ tidak patuh minum obat. Dari 99 responden berusia 36-45 tahun (dewasa tengah) terhadap kepatuhan minum obat, diketahui 74 responden $(74,7 \%)$ patuh minum dan 25 responden $(25,3 \%)$ tidak patuh minum obat. Sedangkan dari 52 responden berusia 46-55 tahun (dewasa akhir) terhadap kepatuhan minum obat, diketahui 28 responden $(53,8 \%)$ patuh minum dan 24 responden $(46,3 \%)$ tidak patuh minum obat.Hasil uji statistik diperoleh nilai $\mathrm{p}$-value $=0,001$ ( $\mathrm{p}>0,05)$, maka dapat disimpulkan ada hubungan yang signifikan antara usia dengan kepatuhan minum obat).

Tabel 2. Analisis Hubungan Jenis Kelamin

Dengan Kepatuhan Minum Obat

Antihipertensi Pada Penderita Hipertensi

Primer Di Kelurahan Limo Depok tahun

2017

\begin{tabular}{|c|c|c|c|c|c|c|c|c|}
\hline \multirow{3}{*}{$\begin{array}{c}\text { Jenis } \\
\text { Kelami } \\
\mathbf{n}\end{array}$} & \multicolumn{6}{|c|}{ Kepatuhan Minum Obat } & \multirow{3}{*}{$\begin{array}{c}P \text { - } \\
\text { value }\end{array}$} & \multirow{3}{*}{ OR } \\
\hline & \multicolumn{2}{|c|}{ Patuh } & \multicolumn{2}{|c|}{$\begin{array}{l}\text { Tidak } \\
\text { Patuh }\end{array}$} & \multicolumn{2}{|c|}{ Total } & & \\
\hline & $\mathbf{n}$ & $\%$ & $\mathbf{n}$ & $\%$ & $\mathrm{n}$ & $\%$ & & \\
\hline $\begin{array}{l}\text { Perempu } \\
\text { an }\end{array}$ & 82 & 65,5 & 43 & 34,4 & 125 & 100 & & $1,294($ \\
\hline $\begin{array}{l}\text { Laki- } \\
\text { Laki }\end{array}$ & 28 & 59,6 & 19 & 40,4 & 47 & 100 & 0,403 & $\begin{array}{l}0,049- \\
2,579)\end{array}$ \\
\hline Total & 110 & 64,0 & 62 & 36 & 172 & 100 & & \\
\hline
\end{tabular}

Hasil analisis dari tabel diatas, meyatakan bahwa dari 125 responden berjenis kelamin perempuan terhadap kepatuhan minum obat, diketahui 82 responden $(65,5 \%)$ patuh minum obat dan 43 responden $(34,4 \%)$ tidak patuh minum obat. Sedangkan dari 47 responden berjenis kelamin laki-laki terhadap kepatuhan minum obat, diketahui 28 responden $(59,6 \%)$ patuh minum dan 19 responden $(40,4 \%)$ tidak patuh minum obat.Hasil uji statistik diperoleh nilai $\mathrm{p}$-value $=0,463$ ( $>0,05$ ), maka dapat disimpulkan tidak ada perbedaan proporsi kepatuhan minum obat antara responden berjenis kelamin perempuan dan laki-laki terhadap kepatuhan minum obat (tidak ada hubungan yang signifikan jenis kelamin dengan kepatuhan minum obat). Hasil analisis termasuk nilai $\mathrm{OR}=1,294$ artinya responden yang berjenis kelamin perempuan 
mempunyai peluang 1,2 kali lebih patuh meminum obat antihipertensi dibandingkan responden berjenis kelamin laki-laki.

Tabel 3. Analisis Hubungan Pendidikan

Dengan Kepatuhan Minum Obat Antihipertensi Pada Penderita Hipertensi Primer Di Kelurahan Limo Depok tahun 2017

\begin{tabular}{|c|c|c|c|c|c|c|c|c|}
\hline \multirow{3}{*}{$\begin{array}{l}\text { Pendidi } \\
\text { kan }\end{array}$} & \multicolumn{6}{|c|}{ Kepatuhan Minum Obat } & \multirow{3}{*}{$\begin{array}{c}\text { P- } \\
\text { value }\end{array}$} & \multirow{3}{*}{ OR } \\
\hline & \multicolumn{2}{|c|}{ Patuh } & \multicolumn{2}{|c|}{$\begin{array}{l}\text { Tidak } \\
\text { Patuh } \\
\end{array}$} & \multicolumn{2}{|c|}{ Total } & & \\
\hline & $\mathbf{n}$ & $\%$ & $\mathbf{n}$ & $\%$ & $\mathbf{n}$ & $\%$ & & \\
\hline Tinggi & 51 & 69,9 & 22 & 30,1 & 73 & 100 & & 1,572 \\
\hline Rendah & 59 & 59,6 & 40 & 40,4 & 99 & 100 & 0,166 & $(0,828-$ \\
\hline Total & 110 & 64 & 62 & 36,0 & 172 & 100 & & \\
\hline
\end{tabular}

Hasil analisis dari tabel diatas, meyatakan bahwa dari 73 responden yang berpendidikan tinggi dengan kepatuhan minum obat, diketahui 51 responden $(69,9 \%)$ patuh minum obat dan 22 responden $(22 \%)$ tidak patuh minum obat. Sedangkan dari 99 responden yang berpendidikan rendah dengan kepatuhan minum obat, diketahui 59 responden $(59,6 \%)$ patuh minum dan 40 responden $(40,4 \%)$ tidak patuh minum obat.Hasil uji statistik diperoleh nilai $\mathrm{p}$-value $=0,166$ ( $>0,05)$, maka dapat disimpulkan tidak ada perbedaan proporsi kepatuhan minum obat antara responden yang berpendidikan tinggi dan pendidikan rendah terhadap kepatuhan minum obat (tidak ada hubungan yang signifikan antara pendidikan dengan kepatuhan minum obat). Hasil analisis termasuk nilai $\mathrm{OR}=1,572$ artinya responden yang berpendidikan tinggi mempunyai peluang 1,5 kali lebih patuh meminum obat antihipertensi dibandingkan responden yang berpendidikan rendah.

Tabel 4. Analisis Hubungan Sikap

Dengan Kepatuhan Minum Obat

Antihipertensi Pada Penderita Hipertensi Primer Di Kelurahan Limo Depok tahun 2017

\begin{tabular}{|c|c|c|c|c|c|c|c|c|}
\hline \multirow{3}{*}{$\begin{array}{l}\text { Sikap } \\
\text { Persepsi }\end{array}$} & \multicolumn{6}{|c|}{ Kepatuhan Minum Obat } & \multirow{3}{*}{$\begin{array}{c}\text { P- } \\
\text { value }\end{array}$} & \multirow{3}{*}{ OR } \\
\hline & \multicolumn{2}{|c|}{ Patuh } & \multicolumn{2}{|c|}{$\begin{array}{l}\text { Tidak } \\
\text { Patuh }\end{array}$} & \multicolumn{2}{|c|}{ Total } & & \\
\hline & $\mathbf{n}$ & $\%$ & $\mathbf{n}$ & $\%$ & $\mathbf{n}$ & $\%$ & & \\
\hline Baik & 73 & 88,0 & 10 & 12,0 & 83 & 100 & \multirow{3}{*}{0,000} & \multirow{3}{*}{$\begin{array}{c}10,259 \\
(4,685- \\
22,468)\end{array}$} \\
\hline Tidak Baik & 37 & 41,6 & 52 & 58,4 & 89 & 100 & & \\
\hline Total & 110 & 64 & 62 & 36,0 & 172 & 100 & & \\
\hline \multicolumn{9}{|c|}{$*$ p-value $<0,05$} \\
\hline
\end{tabular}

Hasil analisis dari tabel diatas, meyatakan bahwa dari 83 responden yang memiliki sikap persepsi baik terhadap kepatuhan minum obat, diketahui 73 responden (88\%) patuh minum obat dan 10 responden $(12 \%)$ tidak patuh minum obat. Sedangkan dari 89 responden yang memiliki sikap persepsi tidak baik terhadap kepatuhan minum obat, diketahui 37 responden $(41,6 \%)$ patuh minum dan 52 responden $(58,4 \%)$ tidak patuh minum obat. Hasil uji statistik diperoleh nilai pvalue $=0,000 \quad(\mathrm{p}<0,05)$, maka dapat disimpulkan ada perbedaan proporsi kepatuhan minum obat antara responden yang memiliki sikap persepsi baik dan tidak baik terhadap kepatuhan minum obat (ada hubungan yang signifikan antara sikap persepsi dengan kepatuhan minum obat). Hasil analisis termasuk nilai $\mathrm{OR}=10,259$ artinya responden yang memiliki sikap persepsi baik mempunyai peluang $10 \mathrm{kali}$ lebih patuh meminum obat antihipertensi dibandingkan responden dengan sikap persepsi yang tidak baik.

Tabel 5. Analisis Hubungan Lama Menderita Hipertensi Dengan Kepatuhan Minum Obat Antihipertensi Pada

Penderita Hipertensi Primer Di Kelurahan Limo Depok tahun 2017

\begin{tabular}{|c|c|c|c|c|c|c|c|c|}
\hline \multirow{3}{*}{$\begin{array}{l}\text { Lama } \\
\text { Sakit }\end{array}$} & \multicolumn{6}{|c|}{ Kepatuhan Minum Obat } & \multirow{3}{*}{$\begin{array}{c}\text { P- } \\
\text { value }\end{array}$} & \multirow{3}{*}{ OR } \\
\hline & \multicolumn{2}{|c|}{ Patuh } & \multicolumn{2}{|c|}{$\begin{array}{l}\text { Tidak } \\
\text { Patuh }\end{array}$} & \multicolumn{2}{|c|}{ Total } & & \\
\hline & $\mathbf{n}$ & $\%$ & $\mathbf{n}$ & $\%$ & $\mathbf{n}$ & $\%$ & & \\
\hline Akut & 38 & 74,5 & 13 & 25,5 & 51 & 100 & \multirow{3}{*}{0,061} & \multirow{3}{*}{$\begin{array}{c}1,989 \\
(0,962- \\
4,115)\end{array}$} \\
\hline Kronis & 72 & 59,5 & 49 & 40,5 & 121 & 100 & & \\
\hline Total & 110 & 64,0 & 62 & 36,0 & 172 & 100 & & \\
\hline
\end{tabular}


Hasil analisis dari tabel diatas, meyatakan bahwa dari 51 responden dengan lama sakit $\leq 6$ bulan (akut) terhadap kepatuhan minum obat, diketahui 38 responden $(74,5 \%)$ patuh minum obat dan 13 responden $(25,5 \%)$ tidak patuh minum obat. Sedangkan dari 121 responden dengan lama sakit > 6 bulan (kronik) terhadap kepatuhan minum obat, diketahui 72 responden $(59,5 \%)$ patuh minum dan 49 responden $(40,9 \%)$ tidak patuh minum obat.Hasil uji statistik diperoleh nilai $\mathrm{p}$ value $=0,061 \quad(p>0,05)$, maka dapat disimpulkan tidak ada perbedaan proporsi kepatuhan minum obat antara responden dengan lama sakit $\leq 6$ bulan (akut) dan $>6$ bulan (kronis) terhadap kepatuhan minum obat (tidak ada hubungan yang signifikan antara lama sakit hipertensi dengan kepatuhan minum obat). Hasil analisis termasuk nilai $\mathrm{OR}=1,989$ artinya responden dengan lama sakit $\leq 6$ bulan (akut) mempunyai peluang 1,9 kali lebih patuh meminum obat antihipertensi dibandingkan responden dengan lama sakit $>6$ bulan (kronik).

\section{b. Analisa Multivariate}

1) Faktor yang paling berpengaruh terhadap kepatuhan minum obat antihiperternsi pada penderita hipertensi primer

\begin{tabular}{|l|l|}
\hline \multicolumn{1}{|c|}{ Subvariabel } & \multicolumn{1}{c|}{ P Value } \\
\hline Usia & 0.978 \\
\hline Jenis Kelamin & 0.525 \\
\hline Pendidikan & 0.149 \\
\hline Lama menderita & 0.069 \\
\hline Sikap & 0.001 \\
\hline
\end{tabular}

Variabel yang akan di uji multivariat adalah variabel independen seperti, usia, jenis kelamin, pendidikan, lama menderita hipertensi, dan sikap dengan variabel dependennya adalah kepatuhan minum obat.Dalam langkah ini kita akan menyeleksi, variabel independen manakah yang layak masuk model uji multivariat. Di mana yang layak adalah yang memiliki tingkat signifikansi (sig.) atau $\mathrm{p}$ value < 0,25 dengan metode "Enter" dalam regresi logistik sederhana. Yaitu dengan melakukan satu persatu regresi sederhana antara masing-masing variabel independen terhadap variabel dependen. Jika hasil tabel "variables in the equation" dan lihat nilai "sig." . Didapat nilai signifikan $<0,25$, yang berarti variabel tersebut layak masuk model multivariate.

Dari hasil seleksi variabel diatas, maka yang layak masuk uji multivariat adalah variabel pendidikan, lama menderita dan sikap karena memiliki nilai $\mathrm{p}<0,25$. Untuk selanjutnya berikut adalah hasil dari uji multivariat ke tiga variabel tersebut:

Tabel 1. Faktor yang paling

berpengaruh terhadap kepatuhan minum obat antihiperternsi pada penderita hipertensi primer

\begin{tabular}{|c|l|c|c|c|c|c|}
\hline No & Subvariabel & B & Wald & Sig. & OR & CI 95\% \\
\hline 1 & Pendidikan & 0,175 & 0.217 & 0,641 & 1,191 & $0,571-2,482$ \\
\hline 2 & Lama Sakit & 0,182 & 0,180 & 0,672 & 1,200 & $0,517-2,782$ \\
\hline 3 & Sikap & 2,282 & 31,010 & 0,001 & 9,793 & $4,387-21,860$ \\
\hline
\end{tabular}

Hasil analisa dapat disimpulkan bahwa dari keseluruhan variabel independen yang diduga mempengaruhi kepatuhan minum obat antihipertensi pada penderita hipertensi primer terdapat satu subvariabel (sikap) yang paling berhubungan dengan kepatuhan minum obat dengan $\mathrm{p}$ value $0,001<0,05$. Nilai OR terbesar yang diperoleh yaitu 21,860 artinya sikap baik yang dimiliki responden mempunyai peluang 21,860 kali untuk patuh minum obat antihipertensi.

\section{Pembahasan}

\section{a. Hubungan usia dengan kepatuhan minum obat antihipertensi pada penderita hipertensi primer}

Bertambah usia seseorang akan semakin banyak permasalahan yang di alaminya terutama terkait kondisi kesehatannya hal ini di sebabkan terjadinya kemunduran fungsi seluruh tubuh secara progresif . Hasil penelitian ini didapatkan nilai $\mathrm{p}$-value $=0,001$ ( $>0,05)$ menunjukan bahwa ada 
hubungan yang signifikan antara usia dengan kepatuhan minum obat. Seseorang yang mengalami pertambahan usia mulai dari dewasa awal,dewasa pertengahan dan dewasa akhir akan mengalami frustasi atau sikap penolakan terhadap penyakitnya sehingga akan mengalami sikap yang tidak patuh terhadap anjuran dokter ataupun obat/terapi yang diberikan oleh dokter/tim medis. Penelitian ini sesuai yang dilakukan ali ami jaya,(2009) menunjukan Dari hasil uji statistik $C h i$ Square. $p$ Value: $0.05(\alpha=0,05)$, didapatkan bahwa usia yang bertambah cenderung patuh minum obat antihipertensi. Penelitian ini diperkuat oleh pendapat Misnadiarly (2006) bahwa umur tua atau lansia mempunyai peluang untuk tidak patuh sehubungan dengan fungsi organ dan daya ingat.

\section{b. Hubungan jenis kelamin dengan kepatuhan minum obat antihipertensi pada penderita hipertensi primer}

Jenis kelamin berkaitan dengan peran kehidupan dan perilaku yang berbeda antara laki-laki dan perempuan dalam masyarakat. Dalam hal menjaga kesehatan biasanya kaum perempuan lebih memperhatikan kesehatanya dibandingkan dengan laki-laki. Hal ini dikarenakan sifat-sifat dari perempuan yang lebih memperhatikan kesehatan bagi dirinya dibandingkan laki-laki (Depkes RI,2013). Perbedaan pola perilaku sakit juga dipengaruhi oleh jenis kelamin, perempuan lebih sering mengobatkan dirinya dibandingkan dengan laki-laki, sehingga akan lebih banyak perempuan yang datang berobat dibandingkan laki-laki (Notoatmodjo, 2010).Hasil penelitian ini memperoleh nilai $\mathrm{p}$-value $=0,463 \quad(\mathrm{p}>0,05)$ menunjukan tidak ada hubungan yang signifikan jenis kelamin dengan kepatuhan minum obat. Penelitian ini mayoritas responden terbanyak yaitu berjenis kelamin perempuan. Tidak semua jenis kelamin perempuan mempunyai perilaku patuh meminum obat antihipertensi, sebanyak $65,5 \%$ patuh meminum obat antihipertensi sedangkan yang tidak patuh sebanyak $34,4 \%$. Dari ketidaksignifikan hasil tersebut dapat dipengaruhi oleh faktor pendidikan pada responden perempuan dimana didapatkan hasil analisa pendidikan rendah sebanyak 57,2\% sehingga karena rendahnya tingkat pendidikan seseorang maka dapat mempengaruhi seseorang untuk dapat patuh meminum obat antihipertensi.

Penelitian ini sesuai dengan penelitian yang dilakukan Puspita exa (2016) menunjukan tidak ada hubungan yang signifikan antara jenis kelamin dengan kepatuhan dalam menjalani pengobatan hipertensi di Puskesmas Gunungpati dengan nilai $p=0,366$ $(p>0,05)$. Hasil penelitian juga menunjukan bahwa mayoritas responden adalah berjenis kelamin perempuan yaitu sebesar $65,5 \%$ dan berjenis kelamin laki-laki sebesar $34,5 \%$. Berbeda dengan penelitian yang dilakukan oleh Alphonche (2012) bahwa jenis kelamin berhubungan dengan kepatuhan pengobatan pasien hipertensi dengan nilai $p=0,044$. Pada penelitian yang dilakukan oleh Alphonce sampel yang digunakan adalah pasien hipertensi berusia 18 tahun keatas, sehingga rentang usia lebih luas. Sedangkan dalam penelitian ini peneliti memfokuskan pada pasien hipertensi dengan rentang usia 45-64 tahun, sehingga hasil dapat berbeda. Dalam penelitianya Alphonce menyebutkan bahwa impotensi adalah efek samping obat antihipertensi yang kemungkinan mempengaruhi kepatuhan minum obat pada responden laki-laki. Sedangkan penemuan dalam penelitian ini pekerjaan diduga menjadi alasan mengapa laki-laki cenderung tidak patuh untuk melakukan pengobatan, hal ini dikarenakan $78 \%$ laki-laki yang 
dinyatakan tidak patuh adalah mereka yang memiliki pekerjaan.

\section{c. Hubungan pendidikan dengan kepatuhan minum obat antihipertensi pada penderita hipertensi primer}

Pendidikan adalah suatu kegiatan atau proses pembelajaran untuk mengembangkan atau meningkatkan kemampuan tertentu sehingga sasaran pendidikan itu dapat berdiri sendiri (Notoatmodjo,2010). Responden yang berpendidikan lebih tinggi akan mempunyai pengetahuan yang lebih luas dibandingkan dengan responden yang tingkat pendidikanya rendah. Hasil penelitian ini bertentangan dengan uraian diatas, nilai $\mathrm{p}$-value $=0,166$ $(\mathrm{p}>0,05)$ menunjukan tidak ada hubungan yang signifikan antara pendidikan dengan kepatuhan minum obat. Pendidikan tinggi dan pendidikan rendah sama-sama mempunyai tingkat kepatuhan yang lebih tinggi yaitu pada pendidikan tinggi sebanyak $69,9 \%$ patuh dan tidak patuh sebanyak 30,1\% sedangkan pada pendidikan rendah sebanyak 59,6 \% dan tidak patuh sebanyak 40,4\%. Hal ini dapat dipengaruhi oleh hasil analisa subvariabel sikap responden yaitu terdapat $88 \%$ seseorang yang mempunyai sikap baik yang patuh meminum obat antihipertensi. Sikap merupakan keyakinan responden untuk patuh dalam meminum obat agar terhindarnya komplikasi dari hipertensi yang diderita responden sehingga dapat meningkatkan kualitas hidup responden.

Penelitian ini sesuai dengan penelitian Kimuyu (2014) menunjukan bahwa tidak terdapat hubungan antara tingkat pendidikan terhadap kepatuhan minum obat antihipertensi di Rumah sakit Kota Kiambu $(p=0,191)$. Dalam penelitian Kimuyu distribusi tingkat pendidikan responden lebih heterogen. Berbeda dengan hasil penelitian puspita exa (2016) menunjukan bahwa ada hubungan antara tingkat pendidikan terakhir dengan kepatuhan dalam menjalani pengobatan hipertensi dengan nilai $p=0,000$. Hasil penelitian ini diperkuat penelitian yang dilakukan oleh Vincent Boima (2015) yang menyatakan terdapat hubungan antara tingkat pendidikan dengan kepatuhan pengobatan hipertensi $(p=0,001)$. Hal ini dikarenakan pada hasil penelitian, dari total responden yang berpendidikan tinggi sebanyak $70,9 \%$ responden patuh menjalani pengobatan dan 29,1\% responden tidak patuh menjalani pengobatan. Sama halnya dengan penelitian yang dilakukan Vincent Boima (2015), pada penelitian ini juga ditemukan bahwa responden dengan pendidikan tinggi akan lebih patuh $85 \%$ dibandingkan dengan responden yang tidak patuh $15 \%$.

\section{d. Hubungan sikap dengan kepatuhan minum obat antihipertensi pada penderita hipertensi primer}

Penelitian ini memperoleh nilai $\mathrm{p}$ value $=0,000(\mathrm{p}<0,05)$ menunjukkan ada hubungan yang signifikan antara sikap dengan kepatuhan minum obat antihipertensi. Sikap seseorang terhadap perilaku kepatuhan menentukan tingkat kepatuhan. Kepatuhan seseorang merupakan hasil dari proses pengambilan keputusan orang tersebut, dan akan berpengaruh pada persepsi dan keyakinan orang tentang kesehatan. Selain itu keyakinan serta budaya juga ikut menentukan perilaku kepatuhan . Nilai seseorang mempunyai keyakinan bahwa anjuran kesehatan itu dianggap benar maka responden akan patuh terhadap minum obat antihipertensi.

Hasil ini bertentangan dengan penelitian yang dilakukan oleh Sangi dkk (2016) belum ditemukan hubungan yang bermakna antara sikap pasien dengan kepatuhan minum obat pada pasien hipertensi. Sangi dkk (2016) beranggapan bahwa Kepatuhan minum 
obat pada pasien hipertensi dapat di pengaruhi oleh motivasi, dalam hal ini motivasi pada responden itu sendiri. Kurangnya motivasi pada penderita hipertensi dapat dipengaruhi oleh lamanya responden menderita hipertensi. Menurut teori Notoatmojo 2010 (dalam Suparyanto 2014), motivasi merupakan dorongan dari dalam diri seseorang yang menyebabkan seseorang tersebut melakukan kegiatan-kegiatan tertentu guna mencapai suatu tujuan.

\section{e. Hubungan lama menderita hipertensi dengan kepatuhan minum obat antihipertensi pada penderita hipertensi primer}

Lama menderita hipertensi dikatakan Semakin lama seseorang menderita hipertensi maka tingkat kepatuhanya makin rendah, hal ini disebabkan kebanyakan penderita akan merasa bosan untuk berobat (Ketut Gama et al, 2014).Sesuai dengan uraian diatas menunjukan hubungan antara lama menderita hipertensi dengan kepatuhan dalam menjalani pengobatan hipertensi diperoleh nilai $\mathrm{p}$ velue $=0,005(\mathrm{p}<0,05)$ yang berarti bahwa ada hubungan antara lama menderita hipertensi dengan kepatuhan dalam menjalani pengobatan hipertensi ( Puspita ,2016).

Penelitian ini memperoleh nilai $\mathrm{p}$ value $=0,061 \quad(\mathrm{p}>0,05)$ maka dapat disimpulkan tidak ada perbedaan proporsi kepatuhan minum obat antara responden dengan lama sakit $\leq 6$ bulan (akut) dan $>6$ bulan (kronis) terhadap kepatuhan minum obat (tidak ada hubungan yang signifikan antara lama sakit hipertensi dengan kepatuhan minum obat). Hasil analisis termasuk nilai $\mathrm{OR}=1,989$ artinya responden dengan lama sakit $\leq 6$ bulan (akut) mempunyai peluang 1,9 kali lebih patuh meminum obat antihipertensi dibandingkan responden dengan lama sakit > 6 bulan (kronik). Hasil ini bertentangan dengan uraian diatas, peneliti beranggapan bahwa seseorang yang lama menderita hipertensi sama saja dengan orang yang mengalami pengobatan hipertensi atau yang menjalani pengobatan sehingga responden yang akut dan responden yang kronis yaitu sama-sama mempunyai tekad untuk sehat dengan mematuhi minum obat antihipertensi untuk memaintance hipertensinya.

\section{f. Faktor yang paling berpengaruh terhadap kepatuhan minum obat antihiperternsi pada penderita hipertensi primer}

Sikap adalah suatu respon atau reaksi seseorang dari suatu stimulus yang diberikan dan akan mendasari seseorang untuk melakukan sesuatu atau menimbulkan perilaku (Rusmanto,2013). Sikap mempunyai beberapa komponen salah satunya adalah komponen afektif yaitu aspek emosional yang berkaitan dengan penilaian terhadap apa yang diketahui manusia (Notoadmodjo,2010). Penelitian ini menunjukkan hasil analisa dari keseluruhan variabel independen yang diduga mempengaruhi kepatuhan minum obat antihipertensi pada penderita hipertensi primer terdapat satu subvariabel (sikap) yang paling berhubungan dengan kepatuhan minum obat dengan $\mathrm{p}$ value $0,001<0,05$. Nilai OR terbesar yang diperoleh yaitu 21,860 artinya sikap baik yang dimiliki responden mempunyai peluang 21,860 kali untuk patuh minum obat antihipertensi.Sesuai yang dikatakan oleh rusmanto (2013), bahwa sikap merupakan reaksi orang yang dapat menimbulkan efek menjadi perilaku, maka dari itu sikap merupakan faktor yang sangat berpengaruh terhadap perilaku patuh dalam meminum obat antihipertensi. Sikap seseorang yang baik akan dapat memunculkan perilaku yang baik juga sehingga seseorang mempunyai keinginan untuk sembuh dengan cara patuh dalam meminum obat antihipertensi. 
Penelitian ini bertentangan dengan penelitian yang dilakukan oleh Sari dkk (2014) menunjukan tidak ada hubungan bermakna antara sikap dengan kepatuhan pengobatan tahap awal $(\alpha=$ $0,05 ; \quad$-value $=0,169)$.penelitian ini diperkuat dengan penelitian sangi dkk (2016) berpendapat bahwa Kepatuhan minum obat pada pasien hipertensi dapat di pengaruhi oleh motivasi, dalam hal ini motivasi pada responden itu sendiri bukan melalui sikap seseorang.

\section{KESIMPULAN DAN SARAN}

Penelitian ini menyimpulkan bahwa ada hubungan Usia ( $\mathrm{p}$-value $=0,001)$, Sikap ( $p$-value $=0,000)$. Sedangkan variabel Jenis kelamin ( $p$-value $=0,463)$, Pendidikan ( $\mathrm{p}$ value $=0,166)$, dan lama menderita ( $\mathrm{p}$ value $=0,061$ ) tidak berhubungan dengan kepatuhan dalam meminum obat antihipertensi pada orang dewasa. Dari semua faktor yang mempengaruhi kepatuhan yaitu variabel sikap ( $p$ value $0,001<0,05)$. Nilai OR terbesar yang diperoleh yaitu 21,860 artinya sikap baik yang dimiliki responden mempunyai peluang 21,860 kali untuk patuh minum obat antihipertensi. Faktor ini sangat mempengaruhi seseorang dalam meminum obat antihipertensi. Disarankan kepada masyarakat harus aktif mengikuti penyuluhan/sosialisasi yang berkaitan dengan hipertensi untuk menambah pengetahuan terutama bagi dewasa sehingga dapat menimbulkan sikap/keinginan masyarakat dalam meminum obat antihipertensi yang gunanya adalah untuk mencegah terjadinya komplikasi dari hipertensi itu sendiri yang diderita masyarakat sehingga dapat meningkatkan kualitas hidup masyarakat. Bagi petugas kesehatan sebaiknya memberikan motivasi kepada masyarakat untuk disiplin dalam meminum obat antihipertensi sehingga dapat memunculkan sikap dan perilaku untuk terus menjaga kualitas hidupnya agar terus sehat. Serta bagi peneliti selanjutnya dapat melanjutkan penelitian sejenis dengan menambahkan variabel penelitian, serta dilakukan analisis untuk menunjukkan besarnya risiko dari setiap variabel.

\section{DAFTAR PUSTAKA}

Anisa dkk.2013.Faktor Yang Berhubungan Dengan Kepatuhan Berobat Hipertensi Pada Lansia Dipuskesmas Patinggalloang Kota Makasar. Jurnal universitas Hasanudin

Ariastuti P. 2014. Faktor-Faktor Yang Mempengaruhi Kepatuhan pengobatan hipertensi Pada Lansia Binaan Puskesmas. Jurnal Ilmiah udayana.

Brunner \& Suddarth. 2005. Keperawatan Medikal Bedah. ED.8 Jakarta: EGC

Budiman, Arif dkk (2013), Faktor Yang Mempengaruhi Kepatuhan Berobat Pasien yang Diterapi dengan Temoxifen Setelah Operasi KankerPayudara, Vol.2, No.1, Tahun 2013

Hitchcock et al, 1999. Community Health Nursing Caring In Action, $2^{\text {nd }}$ Edition, Thomson Learning

Departemen Kesehatan republic Indonesia, 2006. Profil Kesehatan 2005.Jakarta

Departemen Kesehatan RI.2013. Pedoman Teknis Penemuan dan Tatalaksana

Depkes. Pedoman teknis penemuan dan tatalaksana Hipertensi. Jakarta: Direktorat P2PL, 2008

Dinas Kesehatan Provinsi Jawa Tengah. 2012. Buku Profil Kesehatan Provinsi Jawa Tengah. Semarang

Ekarini, Diyah. 2011, Faktor-faktor yang Berhubungan dengan Tingkat Kepatuhan Klien Hipertensi dalam Menjalani Pengobatan di 
Puskesmas

Gondangrejo

Karanganyar, diakses tanggal 6

Oktober

2016 ,

(http://jurnal.stikeskusumahusada.a c.id)

Evadewi, Putu Kenny Rani, 2013, Kepatuhan Mengonsumsi Obat Paien Hipertensi di Denpasar ditinjau dari Kepribadian Tipe A dan Tipe B, Vol.1, No. 1 .

Evadewi, Sukmayanti. 2013. Kepatuhan Mengonsumsi Obat Pasien Hipertensi Di Denpasar Ditinjau Dari Kepribadian Tipe A Dan Tipe $B$. Jurnal Psikologi Udayana 2013, Vol. 1, No. 1, 32-42

Gilang. Korelasi Derajat Hipertensi Dengan Stadium Penyakit Ginjal Kronik DI RSUP DR. Kariadi Semarang Periode 2008-2012. Skripsi Universitas Diponegoro Diunduh tanggal 20 Agustus 2016; 2013

Green, W, Lawrence.et.al, Helath Education Planing A Diagnostik Approach, The Johns Hapkins University: Mayfield Publishing Company, 2005

Hairunisa, 2014, Hubungan Tingkat Kepatuhan Minum Obat dan Diet dengan Tekanan Darah Terkontrol pada Penderita Hipertensi Lansia di Wilayah Kerja Puskesmas Perumnas I Kecamatan Pontianak Barat, diakses pada 4 Oktober 2016 (http://jurnal.untan.ac.id)

Kimuyu, Boniface Mulinge, 2014, Factors Associated with Adherence to Antihypertensive Treatment in Kiambu District Hospital, Disertasi:University of Nairobi

Morisky D, Munter P. New medication adherence scale versus pharmacy fill rates in senior with hipertention. American Jurnal Of Managed Care. 2009; 15(1): 59-66.
Mubin, MF, dkk, 2010, Karakteristik Dan Pengetahuan Pasien Dengan Motivasi Melakukan Kontrol Tekanan Darah Di Wilayah Kerja Puskesmas Sragi I PekalonganVol.6, No.1 Tahun 2013 hal 99-110

Muchid, A. 2006. Pharmaceutical care untuk penyakit hipertensi. Direktorat Bina Farmasi Komunitas dan Klinik Ditjen Bina Kefarmasian dan Alat Kedokteran Departemen Kesehatan

Niven, N. 2002. Psikologi Kesehatan. Jakarta: EGC

Notoatmodjo, S. (2008). Pendidikan dan Perilaku Kesehatan. Jakarta: PT Rineka Cipta.

Notoatmodjo, S. (2010). Pendidikan dan Perilaku Kesehatan. Jakarta: PT Rineka Cipta.

Nursalam.2003. Konsep \& Penerapan Metodologi Penelitian Ilmu Keperawatan: Pedoman Skripsi, Tesis, dan Instrumental Penelitian Keperawatan. Jakarta :Salemba Medika

Palmer, Anna dan Williams, Bryan. 2007. Tekanan Darah Tinggi.Jakarta: Erlangga

Perhimpunan Dokter Spesialis Kardiovaskuler Indonesia .2015. Pedoman Tata Laksana Hipertensi Pada Penyakit Kardiovaskuler,Edisi Pertama, Indonesia : PERKI

Polit, D.F., \& Beck, C.T. 2012. Nursing research : Generating and Assesing Evidence for Nursing Practice. 9th edition. Philadelphia : Lippincot

Puspita. 2016. Faktor-Faktor Yang Berhubungan Dengan Kepatuhan Penderita Hipertensi Dalam Menjalani Pengobatan. Skripsi 
Universitas Negeri Semarang diunduh tanggal 20 Agustus 2016

Riset Kesehatan Dasar. 2013. Pedoman Pewawancara Petugas Pengumpul Data. Jakarta: Badan Litbangkes Depkes

Saepudin dkk, 2011, Kepatuhan Penggunaan Obat pada Pasien Hipertensi di Puskesmas, Jurnal Farmasi Indonesia: Vol 6, No 4, Juli 2013, ISSN: 1412-1107, Hal 246-253.

Sangi dkk. 2016. Faktor -faktor yang berhubungan dengan kepatuhan minum obat pada pasien hipertensi di instalansi gawat darurat $R S$ Bethesda GMIM Tomohon: Vol 6 , Juni 2016;Buletin Sariputra

Sari dkk. 2014. Hubungan Pengetahuan dan Sikap dengan Kepatuhan Berobat pada Pasien TB Paru yang Rawat Jalan di Jakarta Tahun 2014: Vol 26,No 4,Desember 2016,Media Litbangkes

Sastroasmoro \& Ismael. 2011. DasarDasar Metodelogi Penelitian Klinis. Edisi 4. Jakarta : Sagung Seto

Supardi.2013. Metodologi Riset Keperawatan.Jakarta : CV.Trans Info Media

Siti Noor Fatmah .2012. .Kepatuhan pasien yang menderita penyakit kronis dalam mengkonsumsi obat harian. Jurnal univeritas mercubuana Yogyakarta.

The Task Force for the management of arterial hypertension of the European Society of Hypertension $(\mathrm{ESH})$ and of the European Society of Cardiology (ESC). 2013 $\mathrm{ESH} / \mathrm{ESC}$ Guidelines for the management of arterial hypertension. Jour of Hypertension 2013, 31:1281-1357

WHO, 2012, Raised Blood Pressure, diakses tanggal 20 Agustus 2016, (http://www.who.int/gho/ncd/risk_f actors/blood_pressure_prevalence_ text/en/index.html)

WHO , 2012, World Health Day 2013, Measure your blood pressure, reduce your risk, diakses tanggal 20 Agustus 2016 , (http://www.who.int/mediacentre/n ews/releases/2013/world_health_da y_2 0130403/en/)

Wijaya saferi, Putri Mariza, 2013. Keperawatan Medikal Bedah. Nuha Medika: Yogyakarta. 